\title{
Evaluation on the Effects of Different Feed Supplementation on Nutrient Intake, Milk Yield and Economic Feasibility of Holstein Frisian Cross Breed Dairy Cow under Small Holder Farmer: Wondo Genet Woreda, SNNPRS, Ethiopia
}

\author{
Meseret Tsegaye $^{1} \quad$ Otoro olikie $^{2}$ \\ 1.Southern Agricultural Research Institute (SARI), P.O.Box 2126 \\ 2.Hawassa Agricultural Research Centre, P.O.Box 06, Hawassa, Ethiopia;
}

\begin{abstract}
The study was undertaken on farm at Wondo Genet woreda Southern Nations National People Regional State (SNNPRS) Ethiopia, to evaluate the effect of different feed supplements on feed intake, milk yield and economic feasibility of Holstein Frisian cross breed dairy cows under small holder farmers. Twenty four cross breed dairy cows with early lactation mean initial milk yield of $10 \pm 1.34$ (mean \pm SE) lit per cow per day and average initial body weight $388.75 \pm 2.41 \mathrm{~kg}$ (mean $\pm \mathrm{SE}$ ) was used for this research work. The experiment had four treatments with six replications by using a randomized complete block design to which villages was used for blocking. The treatments were; T1, Harvested fresh natural pasture and sole wheat bran $100 \%$. T2, Harvested fresh natural pasture and concentrate mix comprised with wheat bran $66 \%$, noug seed cake $33 \%$ and salt $1 \%$. T3, Harvested fresh natural pasture and concentrate mix comprised with cotton seed cake $33 \%$, wheat bran $66 \%$ and $1 \%$ salt and .T4, harvested fresh natural pasture and Urea molasses block. There was significant $(\mathrm{P}<0.05)$ differences on average crude protein and acid detergent fiber intakes among treatment groups. The average daily Milk yield have significant difference $(\mathrm{P}<0.05)$ among treatment diets. The daily average milk yield increment among treatments liter per cow per day was $3.00 \pm 0.47,2.89 \pm 0.38,2.66 \pm 0.38$, and $0.42 \pm 0.38$; for T4, T2, T3 and T1 correspondingly. The partial budget analysis describes monthly gross profit obtained from milk sale among the treatments was for T4 $=1038.75$ birr, T2 $=956.40$ birr, T3 $=844.20$ birr and $\mathrm{T} 1=-190.80$ birr was observed. Thus, it was concluded that Holstein Frisian cross breed dairy cows at early stage of lactation fed a basal diet of fresh natural grass supplemented with $3 \mathrm{~kg}$ wheat bran and $500 \mathrm{gm}$ UMB per day per cow could be a better strategy to improve the milk yield and income under small hold farmers' management.
\end{abstract}

Keywords: Block; supplement; partial budget; nutrient composition.

DOI: $10.7176 / J N S R / 9-11-05$

Publication date:June $30^{\text {th }} 2019$

\section{Introduction}

Farmers in the tropics and developing countries often rely on the use of exotic genotypes to crossbreed their indigenous cattle so as to improve their milk yield. Because of the differences between the production systems, including climatic factors and feed supply, the performance of the animals resulting from such a breeding programmers may be considerably behind the expectations, eventually indicating a genotype by environment interaction. Ethiopia, despite its large livestock resource base (99.4\% indigenous and the rest crossbreds) and an ecological setting suitable for dairy production, is not yet self sufficient in milk production. Recent report by CSA (2010/11) indicated that the total production of cow milk is about 4.06 billion liters, and this translates to an average daily milk production/cow of 1.86 liters/day. The MoA (2012) also reported some improvement in per capita consumption of milk and estimated it at $19.2 \mathrm{~kg}$. The traditional milk production system, which is dominated by indigenous breeds of low genetic potential for milk production, accounts for about 97 percent of the country's total annual milk production (Felleke, 2003). The low productivity of the country's livestock production system in general and the traditional sector in particular is mainly attributed to shortage of crossbreed dairy cows, lack of capital by dairy producers, inadequate animal feed resources both in terms of quality and quantity, unimproved animal husbandry systems, inefficient and inadequate milk processing materials and methods, low milk production and supply to milk processing centers and poor marketing and market information systems. When we compare indigenous cattle breed with crossbreds require relatively better management in terms of feeding, housing, disease and others, hence crossbreeding when it is an option, should strongly be supported by management. Specially, since feed is the major limiting factor; there should be expanded research on animal feeds and feeding in order to assess the quantity and quality of livestock feed stuffs as well as their value and suitability in low-cost rations balanced for milk production. Therefore, this research was conducted to study on farm evaluation of nutrient supplementation and management technologies in Holstein Frisian cross breed dairy cow at small hold farmers. 


\section{Material and Methods}

\subsection{The study area}

The study was conducted in the SNNPRS, sidama zone at wondo genet woreda, one of the 19 woredas' of sidama zone which is located at the southern part of the zone, at a distance of $263 \mathrm{~km}$ from Addis Ababa Ethiopia (Belaynesh, 2002) and $47 \mathrm{~km}$ from Hawassa the capital of SNNPRS, Ethiopia.(Fekadu, 2006). The average annual rain fall is $1200 \mathrm{~mm}$ per year with annual temperature of $19{ }^{\circ} \mathrm{C}$ (Addisalem, 1997). The altitude range of the area is between 2580 m.a.s.l to 1682 m.a.s.l (Belayenesh, 2003).

\subsection{Management of Experimental Animals}

The study was conducted on farm, by using cross breed Holstein Frisian dairy cows' of dairy producers. The trial was implemented under farmer's management with full follow-up by trained enumerators. During the feeding trial, 24 pregnant dairy cows with eight months of pregnancy were selected. Selection of cows' was based on their month of pregnancy, body condition and health status of the cows. The trial was implemented under farmer's management with full follow-up by trained enumerators. All 24 farmers have dairy cow barn, with waterier and feeder. The experimental cows' offered the basal diet natural fresh harvested grass ad labium and the supplement was offered daily at the proposed level, daily feed supplement in to two parts in the morning at 6: AM and in the afternoon at 6: PM, the house was cleaned daily in the morning before they milking their cow. All animals were within a close supervision by veterinarians. All the farmers' daily routine activities were continued during the experiment period. Milking was performed by the farmers. Before milking, calves were allowed to suckle for about 1 minute to initiate milk let down and after milking for the remaining milk. Trained enumerators were monitor and supervise whether farmers are practicing the data recording properly.

\subsection{Feeding Trial and experimental treatments}

The feeding trial lasted for 60 days following an acclimatization period of 7 days to the experimental treatment diets. $\mathrm{T} 1=$ sole wheat bran, $\mathrm{T} 2=$ wheat bran, noug seed cake and salt, $\mathrm{T} 3=$ cotton seed cake, wheat bran and salt and $\mathrm{T} 4=$ urea molasses block. During the study period three $\mathrm{kg}$ concentrate supplement ( T2 andT3), $3 \mathrm{~kg}$ sole wheat bran T1 and 3kg wheat bran and 500 gram UMB for (T4) was given twice a day at 6:00 AM and 6:00 PM at $(0 \%)$ refusal, respectively. clean drinking water was provided all the time. Daily supplemented feed offered and the refusal was weighed for each animal and recorded throughout the trial period. The daily average feed intake was estimated by the difference between the amounts of feed offered less the amount of feed refused on DM basis. Daily milk yield of each cow was recorded twice every day in the morning and afternoon farmers' customary milking time.

Table 1. Experimental supplementary diets

\begin{tabular}{cllll}
\hline No & Treatments & Basal diet & Supplement & *Replication \\
\hline 1 & T1 & Fresh Natural grass & Sole wheat bran & 6 \\
2 & T2 & Fresh Natural grass & NSC 33\% + WB 66\%+ salt 1\% & 6 \\
3 & T3 & Fresh Natural grass & CSC 33\% + WB 66\% + salt 1\% & 6 \\
4 & T4 & Fresh Natural grass & Wheat bran + UMFB & 6 \\
\hline \multicolumn{2}{l}{ NB:- } & NSC, noug seed cake, CSC: cotton seed cake, UMB: urea molasses block $0.5 \mathrm{~kg} /$ supplement/liter of milk
\end{tabular}

\subsection{Chemical analysis of the feed samples}

The DM content of feed offered and refusal was determined by the standard methods of the Association of Official Analytical Chemists (AOAC, 1990) and ash was determined by igniting the sample in muffles furnace at $5500 \mathrm{C}$ for $3 \mathrm{hrs}(\mathrm{AOAC}, 1990)$. Total nitrogen $(\mathrm{N})$ content of the feed was determined using Micro-Kjeldahl method. The crude protein content was calculated as $\mathrm{N}^{*}$ 6.25. Acid Detergent Fiber (ADF) and Neutral Detergent Fiber (NDF) content were determined according to Van Soest et al. (1991) using in an ANKOM ${ }^{\circledR} 200$ Fiber Analyzer (ANKOM Technology Corp., Fairport, NY, USA).

\subsection{Statistical analysis}

Data on average feed intake and milk yield were analyzed using the General Linear model (GLM) procedure of the statistical analysis system (SPSS). Duncan Multiple Range test was used for comparison of mean differences between treatments. The model used for data analysis was

Yijkl $=\mu+\mathrm{Mj}+\mathrm{Tk}+$ Eijkl (nutrient intake and milk yield) Where; $\mu=$ overall mean;

$\mathrm{Mj}=$ milk yield; $\mathrm{Tk}$ = treatment effect; Eijkl = random error Results was presented as least square means with their standard errors of mean SEM.

\subsection{Partial Budget Analysis}

Partial budget analysis was performed to evaluate the profitability of cross breed dairy cow fed a basal diet of natural grass supplemented with concentrate, sole wheat bran and UMB which was considering the main cost 
component. Economic analysis was done by using partial budget analysis. The price of concentrate feed mix, sole wheat bran, UMB and selling prices of milk was recorded and used for the analysis. The partial budget analysis was employed using the procedure of Upton (1979). The purchasing different input and selling price of milk in each treatment before and after the experiment was considered as total return (TR) in the analysis. The net income (NI) was calculated by subtracting total variable cost (TVC) from the total return (TR). NI = TR-TVC Marginal revenue $\mathrm{MR}=\mathrm{NI} / \mathrm{TVC}$.

\section{RESULTS}

3.1. Chemical Composition of Experimental Feed

Table 2: Chemical compositions of experimental treatment diets

\begin{tabular}{|c|c|c|c|c|c|c|c|c|}
\hline \multirow{2}{*}{$\begin{array}{l}\text { Feed } \\
\text { Items }\end{array}$} & \multicolumn{8}{|c|}{ Nutrients } \\
\hline & DM & OM & $\begin{array}{c}C P \\
\left(6.25^{*} N\right)\end{array}$ & NDF & ADF & $\mathbf{C a}$ & $\mathbf{P}$ & $\begin{array}{c}\text { ME cal } \\
/ \mathrm{kg}\end{array}$ \\
\hline $\mathrm{T} 1$ & 89.14 & 94.48 & 17.31 & 48.64 & 15.10 & 0.10 & 1.16 & - \\
\hline $\mathrm{T} 2$ & 93.62 & 93.83 & 19.62 & 39.27 & 32.42 & 0.34 & 1.16 & 2.44 \\
\hline T3 & 97.84 & 94.26 & 19.06 & 38.90 & 26.25 & 0.19 & 1.30 & 2.57 \\
\hline $\mathrm{T} 4$ & 97.48 & 80.02 & 27.46 & 19.43 & 2.57 & 6.82 & 0.48 & 1.93 \\
\hline
\end{tabular}

$T 1=$ sole wheat bran, $T 2$ and $T 3$ concentrate mix, T4 = Urea molasses block, DM= Dry matter, $C P=C r u d e$ protein, $N D F=$ Neutral detergent fiber, ADF= Acid detergent fiber. Laboratory analysis was worked at Hawassa University Animal Nutrition Laboratory Result

The chemical composition of the sole wheat bran T1 and the three treatment diets concentrate mix and UMB was observed. There was no significant difference in the DM and OM content of the supplemented feed. However, there was lower CP content in sole wheat bran supplementation T1 than concentrate mix T2, T3 and the urea molasses feed block T4. Fiber analysis indicates that (UMB) Urea molasses block T4 contains lower NDF (19.43) than concentrate mix T2 and T3 (39.27 and 38.90) respectively and the highest NDF was obtained in T1 (48.64) the sole wheat bran and lower ADF (2.57) was obtained in UMB.

\subsection{Nutrient intake of Experimental animals}

Table 3: The mean daily nutrients intakes of supplemented feed on Holstein Frisian cross bred dairy cow fed concentrate mix and UMB per day per cow.

\begin{tabular}{|c|c|c|c|c|c|}
\hline \multirow{2}{*}{$\begin{array}{l}\text { Nutrient intake } \\
\text { In kg per day }\end{array}$} & \multicolumn{4}{|c|}{ Treatments } & \multirow[t]{2}{*}{ Sig } \\
\hline & $\mathrm{T} 1$ & $\mathrm{~T} 2$ & T3 & $\mathrm{T} 4$ & \\
\hline DM intake & $2.67 \pm 0.36$ & $3.43 \pm 0.36$ & $3.92 \pm 0.36$ & $3.16 \pm 0.36$ & NS \\
\hline OM intake & $2.53 \pm 0.34$ & $3.22 \pm 0.34$ & $3.69 \pm 0.34$ & $2.92 \pm 0.42$ & NS \\
\hline CP intake & $0.46 \pm 0.07^{\mathrm{c}}$ & $0.67 \pm 0.07^{b}$ & $0.74 \pm 0.07^{\mathrm{a}}$ & $0.60 \pm 0.08^{b}$ & $*$ \\
\hline NDF intake & $1.30 \pm 0.14$ & $1.35 \pm 0.14$ & $1.52 \pm 0.08$ & $1.40 \pm 0.17$ & NS \\
\hline ADF intake & $0.40 \pm 0.11^{\mathrm{b}}$ & $1.11 \pm 0.11^{\mathrm{a}}$ & $1.03 \pm 0.11^{\mathrm{a}}$ & $0.42 \pm 0.13^{b}$ & $*$ \\
\hline
\end{tabular}

$\mathrm{NB}^{*} T 1=$ sole wheat bran, $T 2$ and $T 3$ concentrate mix, $T 4=$ Urea molasses block, DM=Dry matter, $C P=C r u d e$ protein, $N D F=$ Neutral detergent fiber, $A D F=$ Acid detergent fiber

The average voluntary nutrient intake of the experimental dairy cow fed on the four different treatment diets given above in the Table 3. The average dry matter intake of the supplemented treatment diet (DMI) in T3 (3.92 $\mathrm{kg} /$ day/cow) and T2 (3.22 kg/day/cow) and T4 (3.16 kg/day /cow) has no significant differences $(\mathrm{P}>0.05)$ among the three treatments, but higher than T1 $(2.67 \mathrm{~kg} /$ day/cow). However, there was significantly different $(\mathrm{p}<0.05)$ $\mathrm{CP}$ and ADF intake among the four treatments. The low average DM intake recorded in cows supplemented with sole wheat bran, which had relatively lower crude protein content than those supplemented with concentrate mix and UMB, it might be attributed to the higher NDF content of the former compared to the total DM intake. Neutral detergent fiber content is negatively correlated with intake (Arelovich et al., 2008). 
3.3. Milk yield on the experimental dairy cows

Table. 4. Average milk production per cow per day in different villages

\begin{tabular}{|c|c|c|c|c|c|}
\hline \multirow{2}{*}{$\begin{array}{l}\text { Milk yield } \\
\text { Liter/day }\end{array}$} & \multicolumn{4}{|c|}{ Treatments } & \multirow[b]{2}{*}{ Sig. } \\
\hline & $\mathrm{T} 1$ & $\mathrm{~T} 2$ & T3 & $\mathrm{T} 4$ & \\
\hline $\begin{array}{l}\text { Average milk yield } \\
\text { *Pre- treatment } \\
\text { Average milk yield }\end{array}$ & $9.50 \pm 1.34$ & $10.50 \pm 1.38$ & $10.58 \pm 1.34$ & $10.13 \pm 1.64$ & NS \\
\hline *Post - treatment & $9.92 \pm 1.21^{\mathrm{b}}$ & $13.39 \pm 1.21^{\mathrm{a}}$ & $13.25 \pm 1.21^{\mathrm{a}}$ & $13.13 \pm 1.48$ & * \\
\hline $\begin{array}{l}\text { Average milk yield } \\
\text { increment }\end{array}$ & $0.42 \pm 0.38^{\mathrm{c}}$ & $2.89 \pm 0.38^{b}$ & $2.66 \pm 0.38^{b}$ & $3.00 \pm 0.47^{\mathrm{a}}$ & $*$ \\
\hline $\begin{array}{llr}\text { Percentage } & & \text { milk } \\
\text { increased } & \text { over } & \text { per }\end{array}$ & 4.42 & 27.52 & 25.14 & 29.61 & \\
\hline
\end{tabular}

$N B^{*} T 1=$ sole wheat bran, $T 2$ and $T 3$ concentrate mix, T4= Urea molasses block, DM= Dry matter, $C P=C r u d e$ protein, $N D F=$ Neutral detergent fiber, $A D F=$ Acid detergent fiber

The effect of dietary treatment supplementation at early lactation on milk yield on cross breed dairy cows shown in Table 4 . The results showed that, milk yield was significantly affected $(p<0.05)$ by the type of nutrient supplement. Supplementation of cross bred dairy cows that fed urea molasses block, WB and concentrate supplement was superior over sole wheat bran in daily milk yield increment T4(3 liter per day per cow), T2 (2.89 liter per day per cow), T3(2.66 liter per day per cow), T1 (0.42 lit per day per cow). In this study daily milk yield has significantly different in T4 (3 liter per day per cow) supplementing UMB than was higher than the study of J.C.B. Plaizier et al. findings 1.5 liter per day per cow and 1.65 increment per cow per day Tekeba E, et.al.(2013)milk yield increment during their experimental period. These findings Percentage milk increased over per treatment $29.61 \%$ was higher than, Upreti et al. (2010) observed that average total daily milk production per animal increased by $17.7 \%$ (i.e. 1.1 lit./day and Avila (2006) found 21.0\%). However Mandal et al. (2001) reported higher increase (49.76\%) in milk yield in UMMB supplementation group, Singh et.al (2003) reported that UMMB supplementation improved milk yield in buffaloes 35.97\%. Misra et al. (2006) reported that cows supplemented with UMMB produced $30 \%$ more milk than present study.

\subsection{Partial budget analysis}

Table 5: Partial budget analysis on daily milk yield difference of cross breed dairy cow fed a basal diet of natural grass; supplemented with different types of concentrate mixtures and urea molasses feed block.

\begin{tabular}{|c|c|c|c|c|}
\hline \multirow[b]{2}{*}{ Parameters } & \multicolumn{4}{|c|}{ Treatments } \\
\hline & T1 & T2 & T3 & T4 \\
\hline Initial Average milk yield per day & 9.50 & 10.50 & 10.58 & 10.13 \\
\hline Final Average milk yield per day & 9.92 & 13.39 & 13.25 & 13.13 \\
\hline Average milk yield difference per day & 0.42 & 2.89 & 2.66 & 3.00 \\
\hline Cost of milk per liter (ETB) & 17 & 17 & 17 & 17 \\
\hline Pre treatment average milk yield cost (ETB) & 4845.00 & 5355.00 & 5395.80 & 5166.30 \\
\hline $\begin{array}{l}\text { Post treatment average monthly milk yield cost } \\
\text { (ETB) }\end{array}$ & 5059.20 & 6828.90 & 6757.50 & 6696.30 \\
\hline A. Total gross income(ETB) & & & & \\
\hline $\begin{array}{l}\text { Total income difference in a month ( ETB) } \\
\text { Feed cost }\end{array}$ & 214.20 & 1473.90 & 1361.70 & 1530.00 \\
\hline $\begin{array}{l}\text { Total Cost of concentrate supplement ETB } \\
\text { B. Total input cost(ETB }\end{array}$ & 405.00 & 517.50 & 517.50 & 491.25 \\
\hline Gross profit (A-B) & -190.80 & 956.40 & 844.20 & 1038.75 \\
\hline Marginal revenue (A/B) & -0.53 & 2.85 & 2.63 & 3.11 \\
\hline
\end{tabular}

As partial analysis showed that, monthly income from milk off take of experimental cow in different nutrient supplementation was $\mathrm{T} 4>\mathrm{T} 2>\mathrm{T} 3$ and lower in $\mathrm{T} 1$. Gross profit obtained from the supplemented treatment diets $(1038.75,956.40,844.20$ and -190.80), T4, T2, T3 and T1 respectively. In this case the cow fed supplements of concentrate mix and UMB have been economically meaningful for crossbred dairy cows at smallholding farmers. However, a greater increase was observed in UMB supplemented group on income from milk sales as compared to other supplemented groups in crossbred dairy cows under farmers' management.

\section{Conclusions and Recommendation}

The present study revealed that there was significant difference on average milk yield among four treatment diets at early stage lactation of Holstein Frisian cross breed dairy cow under farmers' management. The supplementation of concentrate mix (T2, T3) and UMB (T4) exerts an overall positive effect on average nutrient intake, milk 
production and milk sale. But, T1 sole wheat bran supplementation has a negative effect on nutrient intake, milk yield and income from milk sell. The average milk yield increment was $(\mathrm{T} 1=0.42 \mathrm{liter} / \mathrm{day} / \mathrm{cow}, \mathrm{T} 2=2.89$ liter/day /cow, T3=2.66 liter/day /cow and T4=3 liter/day/cow) and the average income from milk sale $(\mathrm{T} 4>\mathrm{T} 2>\mathrm{T} 3>\mathrm{T} 1)$ 1038.75, 956.40, 844.20 and -190.80 correspondingly. However, UMB supplemented group of experimental animals were better performing than the other two concentrate mix supplemented groups and the sole wheat bran supplemented group. It can be concluded that at early lactation period of Holstein Frisian cross breed dairy cow fed a basal diet of fresh natural grass supplemented with $500 \mathrm{gm} \mathrm{UMB} /$ day /cow and $3 \mathrm{~kg}$ of wheat bran per day per cow could be a better strategy to improve the milk yield and income under small hold farmers' management.

\section{Acknowledgements}

The authors would like to express their gratitude to all who have assisted and supported this study, particularly (SARI) Southern Agricultural Research Institute and Hawassa agricultural research center, AGP (Agricultural Growth Program) for the donation of the research fund, during the research time monitoring and evaluating the work at farmers' level and reviewing during the planning phase of the experiment. I would like to extend my appreciation to DR. Yisehak Kechero, Associate professor at Arba- Minch University, for his comments and suggestions. I deserve great appreciation to the staff members at wondo genet woreda Livestock and fishery office and the three village livestock development agents are gratefully acknowledged for their permanent assistance in data collection and overall support.

\section{Reference:}

Alemayehu Mengistu. 2005. Feed resources base of Ethiopia: Status and opportunities for integrated development. Proceedings of the 12th Annual Conference of the Ethiopian Society of Animal Production (ESAP). Addis Ababa, Ethiopia. pp. 377 - 386.

Alemu Yami and Merkel R.C. 2008. Sheep and goat production hand book for Ethiopia,Addis Ababa, Ethiopia.

AOAC (Association of Official Analytical Chemists). 1990. Official Method of Analysis, 15 thfifteenth, eds. Association of official Analytical, INC., Arlington, Virginia, USA. p.1298

Avila, H.F. (2006). Production and utilization of urea molasses mineral block (UMMB). FAO/Ag/AGP/doc./ Publicat./VIET95, pp.199-204.

CSA, 20010/11. Agricultural sample survey 2010/2011. Vol. II. Report on livestock and livestock characteristics.Statistical Bulletin. Addis Ababa, Ethiopia:

ARO (Ethiopian Agricultural Research Organization). 2001a. Small ruminant research Strategy: EARO (Ethiopian Agricultural Research Organization), Addis Ababa. p.59.

J.C.B. Plaizier et.al. Supplementation of dairy cows with nitrogen molasses mineral block and molasses urea mix during the dry season; Department of animal and poultry science, University of Guelpa, p 735 (1986).

Kunju, P.J.G "Urea molasses block lick: A feed supplement for ruminants" Proceedings of the

International Workshop, Kandy, Sri Lanka p261 (1986)

Misra, A. K., Reddy, G. S. and Ramakrishna, Y.S.(2006). Participatory on-farm evaluation of urea molasses mineral block as a supplement to crossbred cows for dry season feeding in rain fed agro-ecosystem of India. Livestock Research for Rural Development 18:1-8.

Sansoucy, R.R. "Manufacturing of molasses-urea blocks" World Animal Review 57,40 (198

Singh, Parasu Ram and Singh, Mahendra (2003). Effect of UMMB supplementation on milk production in buffaloes and cows. An on-farm trial. Indian J. Anim. Nutr. 20(1):1-5.

Tekeba E., Wurzinger M., Baldinger L., Zollitsch W. J., 2013. Effects of dietary supplementation with urea molasses multi-nutrient block on performance of mid lactating local Ethiopian and crossbred dairy cows. Livestock Research for Rural Development 25 (6) 2013. 
Fig.1. On farm evaluation of different feed supplements in milk yield of early lactating Holstein Frisian cross breed dairy cow

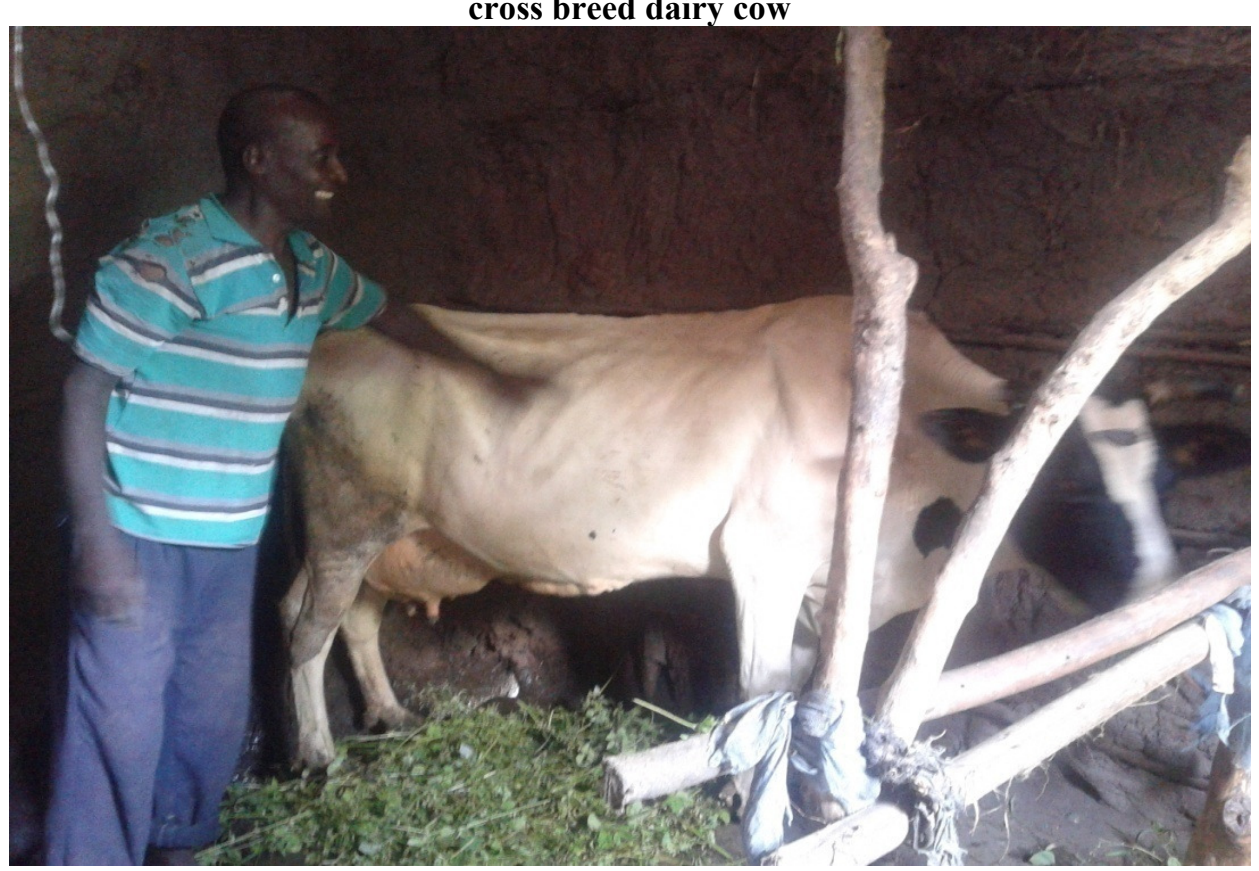

Fig.2. milk production per treatment per day and milk increment

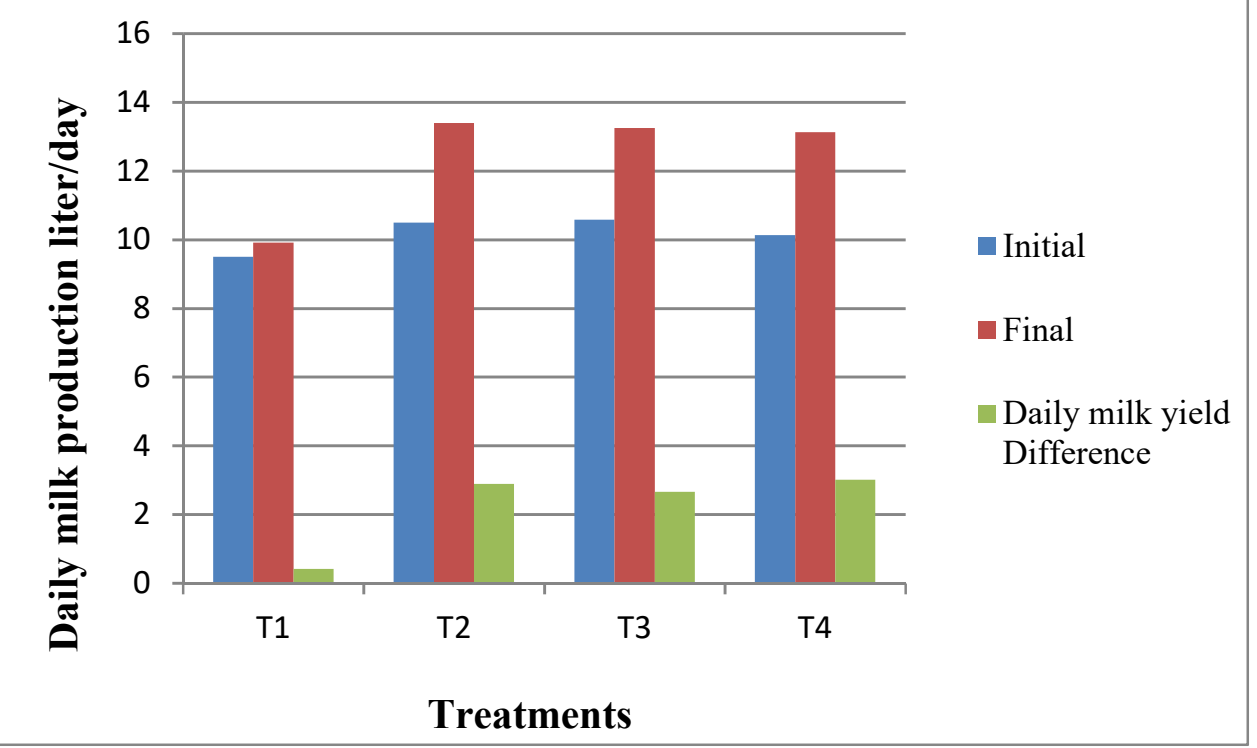

